\title{
Offices in the church: contemporary questions and suggestions (proposals) ${ }^{2}$
}

Pieter Coertzen

Department of Ecclesiology

University of Stellenbosch

STELLENBOSCH

\begin{abstract}
Offices in the church: contemporary questions and suggestions (proposals)

In this article which deals with the offices in the Church attention is given to a few contemporary questions with which Reformed theology is confronted today. Apart from the questions which are identified the article also attempts to contribute to possible answers that can be proposed. Some of the issues identified as relevant in the current debate on the offices are the following: the view of Scripture, the view of the church, the fact of offices in the church, the question of office or service, the functionalisation and horizontalization of the offices in the church, charisma and office and the authority of offices in the church.
\end{abstract}

\section{Introduction}

Offices in the church have become the subject of theological discussion and of theological questioning. There are even theologians who believe that the situation has become a crisis (Jonker, 1970:8; Trimp, 1982:213 f.). Discussions concerning the offices are held in churches of the Reformed tradition, in Roman Catholic Churches as well as in charismatic circles and in the ranks of the World Council of Churches (WCC).

2 Paper delivered at the International Theological Congress: "The Vitality of Reformed Theology", 20-24 June 1994, held at Noordwijkerhout, The Netherlands. Financial support by the Centre for Science Development (HSRC South Africa) to attend the Congress is hereby acknowledged. 
Offices in the church are investigated and discussed from different angles and with different motives.

The theological legitimization of the offices in the church, also an issue in Reformed circles, is one of the questions that will be dealt with in this article. There are those who argue that the legitimization of offices in the church has been wrong up to now and that it should be changed to take more cognisance of present day circumstances. G. Dekker, in his study De stille revolutie. De ontwikkeling van de Gereformeerde Kerken in Nederland tussen 1950 en 1990 (1992), proved that issues such as these can lead to a complete change, not only in the character of the offices in a church, but can eventually also lead to a change in the character of a whole church denomination. This fact alone indicates very clearly that it is of the utmost importance for Reformed theology not only to reflect on the nature of offices in the church, but also to clarify its own viewpoint in this regard.

In this article I would like to pose some of the current questions regarding the offices in the church, and to suggest some answers that can be given from the side of Reformed theology.

\section{Questions asked and suggestions made}

\subsection{Scripture}

At present some of the most fundamental questions posed regarding offices concern the normative role of Scripture in the legitimization and the functioning of offices in the church. To C. Trimp the fundamental reason for contemporary conflicts regarding the offices is that the Word itself is being questioned.

The real crisis around the office on which we are being addressed from all sides is at its deepest level the crisis brought about by criticism of the Scriptures. And as the normativeness of the Holy Scriptures is forced back, another normativeness forces itself up: the social-communicative action within the cadre of the ideal fellowship (Trimp, 1982:213).

The South African New Testament scholar G.M.M. Pelser, in an article "Die bedieninge van die Nuwe Testament. 'n Ondersoek na historiese wording en prinsipiële regverdigbaarheid" (The ministries in the New Testament. An investigation regarding historical development and 
fundamental justification) departs from the premise that the Bible is a book of many different writings with different ways of theological thinking. He therefore arrives at the conclusion that the New Testament picture of the offices is so diverse that a variety of models can be discerned: it is impossible to harmonise them into one system. According to him a definite development from the charismatic to the institutional exists. In this process certain ministries have become church offices by ordination, thereby inhibiting charismatic ministries and causing a division between church office and 'laity'. His own solution is that each denomination should be free to choose a model or develop a structure which will best suit its own needs and circumstances. Provision must be made for the central and fundamental ministry, namely the responsible proclamation of the gospel, to be pursued. Furthermore, every member of the congregation should be enabled to exercise his or her charisma in a meaningful way and thus to benefit the body of Christ (Pelser, 1990:1). L.M. Heyns apparently subscribes to the ideas of Pelser when he states that there are different models of ministries and offices in the Bible: Biblical authority for one so-called model at the cost of other models cannot be claimed (L.M. Heyns, 1993:356). We find a similar approach in the publication edited by Lukas Vischer - Eldership in the Reformed Churches Today (1990). This report states:

On the basis of our knowledge of the Bible today, we believe that Scripture does not point to one single church order, and that any effort to impose such an order on Scripture should be abandoned (Vischer, 1990:8).

The report continues: "One clearly defined church order will be discemed only through selective reading and weighing of some biblical passages over others" (Vischer, 1990:9). Instead of this, the publication pleads for an approach to offices in the church which starts with:

God's great message of salvation for the world and the divine calling of the church for mission. Within that context, we may then inquire: What tasks of ministry are necessary if the church is to fulfil that calling? What leadership is required to guide the whole church in faithfullness to that calling? How is that leadership to be chosen and to work together - with the whole church to the glory of God, for the building up of the Church and the salvation of the world (Vischer, 1990:9).

It is indeed true that many contemporary theologians, including those within the Reformed world, read the Bible as a mere collection of 
historical documents. This approach takes no cogniscance of the Bible's unity, its specific perspective and its specific interpretational framework that has been supplied by the long history of the church's reading and interpretation of it (Jonker, 1994:20).

To my mind this approach to the Bible - as a collection of different writings with very little, if any coherence - is typical of an approach in which Scripture is loosened from its original historical context and the way in which it was understood by the church through the ages. It seems significant that John Calvin in his theology concerning the offices, continuously refers to the way in which Scripture was used and understood in the early church. The fact that he used this historical evidence to guide him in his own formulations on the offices is also significant. Such an approach towards Scripture can have and has had very specific results regarding not only the structuring of the congregation but also specifically the offices in the church. In practice, it can lead to congregationalism (Dingemans), independentism and even, what is called for by some, privatization of the office (Grey, 1990:v). In some cases it even raises the question whether offices are still essential for the church, or merely functional (L.M. Heyns, 1992:52 f.). To my mind such an approach will inevitably lead to great harm. Church unity, the building up of the church and its spirituality will all be affected, even though this is possibly not the intention of the proponents of such viewpoints.

Reformed theology has always laid great emphasis on the unity of Scripture as the revelation of God. Van 't Spijker has pointed out quite correctly that we can only claim sola Scriptura if we maintain tota Scriptura (Van 't Spijker, 1993:325). It cannot be accepted that the Bible is a mere collection of different theological writings. The Bible is the one revelation of God which also contains, amongst other things, guidelines for the structuring of the church and its offices (J.A. Heyns, 1992:8). The Reformed confessions of faith also attest to this fact (Confessio Belgica, art. 30; see also articles 5 and 7). Reformed theology will have to maintain this fundamental point of departure regarding its view of Scripture and its confession of what Scripture teaches on the offices in the church.

In maintaining this viewpoint more often than not Reformed theology is 
accused of fundamentalism. It should be stated and clearly understood that Reformed theology is not fundamentalistic in the sense that American fundamentalism is (Stonehouse, 1958:93 f.; Deist, 1989:2 f.; Berkouwer, s.a.:215 f.). Nevertheless, Reformed theology does have certain basic Biblical data, foundations or principles from which it practises theology, and therefore it also has an ecclesiology and a spirituality. These foundations or principles are founded in the concurrence of the Word and the Spirit, and are expressed in the historical confession of the church that Jesus Christ is the Son of God. These foundations and principles must never be maintained in a self-righteous or Pharisaical way. On the other hand, we dare not forsake these if we really want to build the flock of Christ.

The fact that we accept these foundations means that we - in sympathy with the church throughout the ages - must also find the Scriptural foundations or principles for the structure of the church, its offices and its official ministries. As far as the Old Testament is concerned, it must always be seen in the light of its fulfilment in Christ. In this sense, the Old Testament offers very valuable material regarding the offices which present day Reformed Theology must take into account. As regards the New Testament, it is not true that the gospels teach different principles concerning the offices than does Peter or Paul, for instance. The basic principles or foundations that Scripture gives on the offices in the church are the same and they complement each other as they are given in various parts of Scripture. It is the task of theology (i.e. Reformed theology) to find and formulate these foundations in Scripture.

I believe that it is wrong/incorrect to begin by saying "Scripture does not point to one single church order, and that the effort to impose such an order on Scripture should be abandoned" (Vischer, 1990:8.) Scripture does not give us a church order at all. Scripture gives us the foundations or principles that ought to be brought to a structure (a church order) by every church in accordance with its own position in history. Church orders are made by churches in a certain period and in accordance to the time in which they are made. They are better or worse, in so far as they take into account all the God-given foundations for the church/offices and as they succeed in being a living witness of continuing obedience to the Word of God. 
This does not, however, mean that Reformed theology must ignore the latest viewpoints in Biblical research and in other fields of research, or that it should not also make use of the findings of these scholars - on the contrary. Some very valuable insights have been revealed by Biblical and other scholars, speciflcally with regard to the offices in and the governing of the church. It would be shortsighted not to make use of these conclusions or to evaluate these results critically. The starting point must, however, be the acceptance of the unity of the Bible as the Word of God and not the reading of the Bible as a collection of books by a variety of authors.

\subsection{The church}

It seems as if the position of Reformed theology on the offices in the church is also challenged by the call for a new theological approach to the church. In the past, it was said that pastoral theology focuses on the pastor and his actions in the congregation. Theories for church practices were based on the actions of the pastor. In our time, however, the emphasis has shifted from the pastor to the congregation. The congregation, and not the pastor, has become the subject of actions in the church. In effect this means that there has been a shift away from a theology of offices in the church to a theology of the congregation. This can also be expressed as a shift from a dogmatic ecclesiology to a practical-theological ecclesiology (L.M. Heyns, 1993:356).

This whole issue is also manifested by the way in which the so-called 'shepherd-flock' model of the church is contrasted with the so-called 'body-of-Christ' model. The first model is an example of the dogmatical ecclesiology and the second is an example of the practical-theological ecclesiology. By implication, this new approach has laid a much greater emphasis on the role of the 'laity' in the church as is evident in publications such as Lay people in the Church, a Study for a Theology of the Laity (1952) by Yves Congar, A Theology of the Laity (1958) by Hendrik Kraemer and $A$ Theology of Personal Ministry. Spiritual Giftedness in the Local Church (1981) by L.O. Richards and Gib Martin.

This approach not only has far reaching consequences for the offices in the church but it also challenges Reformed theology. This approach maintains that all believers are ordained into a ministry through their 
baptism. There is therefore no need for the ordination of offices in the church or even for the laying on of hands any more. It states that by the second half of the twentieth century this approach has freed church members both theologically and ecclesiastically (Heyns, 1993:358-359).

Reformed theology needs to be very clear on the questions and the implications which this approach poses. The priesthood of every believer is something that cannot be be denied. It will be a great mistake if the denial of the believer's priesthood should ever enter Reformed theology. History has shown, however, that there is always the real danger of spiritualism if the very important connection between the Spirit and the Word is not maintained throughout. The priesthood of every believer means that every believer has the right to minister his/her fellowman. This, however, is not the only principle of which we read in Scripture and which must be taken into account in the structuring of the church. Ephesians 4:11 ff. also tells us that "he gave some ... for the perfecting of the saints, for the work of the ministry ...". Versteeg (1988:51) formulates this aspect of ministry thus:

Christus heeft niet slechts voor alle gelovigen eigen gaven gegeven, Hij heeft ook uit de kring van de gelovigen sommigen gegeven die als speciale dienst hebben er zorg voor te dragen, dat de aan allen geschonken gaven op de juiste wijze functioneren. In deze speciale dienst is niets anders dan - wat wij noemen - een ambt te onderkennen (Versteeg, 1988:51).

[Christ did not only give gifts to all the believers. From the midst of the believers $\mathrm{He}$ also gave some who have the specific ministry to see that the gifts of all the believers function in the right way. This specific ministry is nothing other than that which we call an office in the church.]

It is also with specific reference to the functioning of gifts that Paul writes to the Corinthians that "God is not the author of confusion, but of peace, as in all the churches of the saints. ... Let all things be done decently and in order" ( 1 Cor. 14:30, 33). Just as Reformed theology cannot deny the fact of the priesthood of all believers, so it also cannot deny the fact of offices in the church and of the specific ministry that they have to fulfil in the church. Similarly the office bearers are called by Christ through the congregation to this ministry. This approach grants every office bearer in the church a place in the midst of the congregation and also binds him to the congregation. At the same time, he has a mission/calling to fulfil within the congregation in the Name of Jesus Christ. In this sense office 
bearers represent Christ for/to the congregation. For instance, it is not fitting for each and every one to climb onto a pulpit and start preaching. To fulfil this ministry, one has to be sent, and this mission emerges through the charisma which God has given (Van 't Spijker, 1993:190 f.).

The question facing Reformed theology is not that of a dogmatic ecclesiology (offices from above) in contrast to a practical-theological ecclesiology (charismatic church members from below), where the solution would lie in the one being freed from the other. It is rather a question of Christ the Lord giving gifts to all His members and assigning a specific public ministry to some members. These members have to fulfil this mission in the name of Christ in the midst of the congregation, aiming to add to the benefit and the building up of the whole congregation.

\subsection{The fact of offices}

The discussion whether offices still have a right to exist is often motivated by the church's quest for the most appropriate form of church organization that will enable them to preach the Gospel in the world and to shape their service of the Lord (Van Ginkel, 1975:5).

In his report of 1970 , Berkhof questions whether the traditional offices can still serve to build the Christian community in modern society. According to him, a discrepancy has arisen between the role expectation of the congregation regarding the minister and the minister's own view of his office. The congregation still expects a genial, paternal figure and a faithful home visitor to attend to them in their joy and in their sorrow. The minister, however, feels that he is expected to perform tasks that can be better handled by others. Berkhof sees in this discrepancy the reason why many theological students are not prepared to make themselves available for ministerial office, but would rather perform specialized tasks (Berkhof, 1970:57 f.).

In his work De Kerk binneste buiten (The church inside out) (1965) J.C. Hoekendijk goes much further than Berkhof. He asserts that we should do away with that massive block which we call the 'church' because it stands between modern man and the message of Christ: the message of the Kingdom. The church, with its offices, church orders, traditions and codes, as well as its unworldly and prudish lifestyle dare not worm its way 
between modern man and Christ. The church is only the vehicle which carries the Gospel into the world, and, as such, only exists to the extent that it performs this duty. This means that the church does not exist, but happens, only in so far as the Gospel message is conveyed and to the extent that the church allows itseif to be used as an instrument in the hands of Jesus Christ, the real apostle. Ultimately, the church is only a function of the apostolate (Hoekendijk, 1964:51). But this apostolate according to Hoekendijk - has nothing to do with the traditional offices of the church, but rather has everything to do with the dynamics of the lay apostolate (mission). For Hoekendijk, the church is mission; and its structures should reflect this apostolic function rather than 'worm' itself between modern man and Christ' s message as has been done in the past. To give effect to this change of emphasis, the 'monumental complexes' which characterise many church buildings should give way to buildings that resemble tents. The large official structures should be replaced. Instead of the congregation meeting in a large meeting place smaller groups, consisting of people drawn from similar vocational or social backgrounds, such as students, nurses, flat dwellers, the aged and military personnel, should come together (Hoekendijk, 1965:92). This structure would enable the church to meet the needs of our modern mobile society more efficiently. It would also mean that the church could do away with offices. Since modern members of the church are mature individuals, they will assert structures against the offices because they are seen as levers of conservatism, guardianship and hierarchy in the church (Hoekendijk, 1965:90 f.; Deddens, 1988:36-37).

There are people, like Dingemans $(1987: 116,121)$, who assert that offices in the church do not rest on Biblical grounds but that they are the result of an historical development in the early Christian church. For definite reasons - inter alia a lack of spiritual power - a need has arisen to give a more permanent form to certain services in the church. The church offices were created to meet this need.

One result of this point of view is that church members are empowered to establish and to abolish offices arbitrarily. It also allows that a church without offices would then be proof of a church with higher spiritual maturity than one with offices. 
This raises the question whether the above interpretation is indeed what the Bible teaches on the origin of the office. 1 Corinthians 12:28 refers to people to whom God has given a particular task. Ephesians 4:11 refers to the gifts of apostles, prophets, evangelists, ministers and teachers which Christ gave to equip the believers for service. In Acts 20:28 Paul warns the elders of Ephesus: "Keep watch over yourselves and over all the flock of which the Holy Spirit has given you charge". Peter writes to the elders about those "whom God has entrusted to you". All these pronouncements are too explicit to enable one to admit that the offices are merely the result of an historical development. This is indeed God's order for His church. It is part of the way that God used to fill everything with the presence of Christ (Ephesians $3: 19 ; 4: 10$ ). It has already been said that the special office has originated from the deed and gift of the Holy Trinity (Van Ruler, 1965:89)

To this discussion on the origin of the office should be added the observation that the office arises from the ranks of the members of the congregation. These members must therefore be closely involved in the identification and placing of a fellow-member in an office function in and for the congregation (cf. Acts $6: 3 ; 6: 5 ; 6: 6 ; 13: 3$ and 14:23). The believers in Jerusalem were told by the apostles that they had to look for seven men, full of the Holy Spirit and of wisdom, who could be appointed for a specific task (Acts 6:3). This injunction met with the approval of the believers and they elected the men (Acts 6:5). After the men had been chosen, it was the believers who took them to the apostles to pray for them and to lay hands on them (Acts 6:6). Acts 13:3 records how the Holy Spirit commissioned the prophets and ministers, who were meeting in Antioch, to set apart Paul and Barnabas to do the work to which He had called them: "... then, after the congregation fasted and prayed they laid their hands on them and let them go". In Acts 14:23 we read that elders were chosen in every congregation and after the congregation had fasted and prayed they committed them to the Lord in whom they had put their faith.

The fundamental motivation underlying the fact of offices in the church comes from the Word of Jesus Christ Himself. He is the One who served to the utmost and who, with the Father and the Holy Spirit, still calls and appoints His servants to render service to His flock. The service of Christ 
is therefore of fundamental and decisive importance for the service and office of His church (Van Genderen \& Velema, 1992:664; Trimp, 1988:240).

\subsection{Office or ministry}

Present day discussions on offices in the church have been complicated by confusing and unclear concepts. Some see the concept office itself as problematic. For some it is quite acceptable given certain assumptions, while others prefer the concept service, especially as it is used in the Bible. It is also clear that there is often a difference of opinion on the concept office as such. This difference lies not only in everything that a office holds but also in the fact that it is often understood differently as a result of definite preconceptions.

Other concepts and expressions complicating the debate on the office are for example the distinctions made between a general and a special office, the office of the believer and his priesthood, official versus spontaneous service, official and specific services, ordered and unordered services, and ordinary services (minister, elder and deacon) and extraordinary services (apostle, prophet and evangelist).

The question how many offices are found in Reformed churches should also be considered. For example: are there only ministers, elders and deacons, or can there also be more offices in a Reformed church than those mentioned here?

In last instance clarity is needed in discussions regarding the meaning of concepts and matters such as calling, gifts and services, the holding of an office, the laying on of hands, office and charisma, as well as the relation between these concepts and other matters.

If Reformed theology is to be seen as relevant in our day, then it must be clear on all the above-mentioned concepts and expressions and any others that might arise.

Among the gifts and services given by the Holy Spirit to the church a certain category exists that in some churches came to be known as 'offices' in the course of the history of the church (Church Order 1990; Art. 3, Dutch Reformed Church). In other churches this category is 
spoken of as the 'services', while others still have what they call 'ordained services' in the church as distinct from other existing ministries (BEM report, 1982). A workable distinction which can eliminate much confusion appears to be that of ministry and official ministry [diens en ampsdiens]. Van Ruler points out that both the terms office and ministry are problematic and need clarification when used (Van Ruler, 1952:67). The fact remains that within the totality of service in the church the service of some takes on a unique character.

The difference between office services and the other services in the church is indicated in several ways. To some, the characteristics of the office service are manifested in the following way:

* The office service orders the functioning of the other services in the church.

* The office service shows a regular and continuous character and

* it has received power of attorney from Christ for the performance of this ministry over and against the congregation (Trimp, 1982:118).

Others discern the typical character of the official ministry in the church as the service of some for the sake of all the others. Expressed differently, this means that the official ministry of the church has arisen from its obligation to equip, to care for and to give guidance to all the ministries in the church. The official ministry should ensure that all believers have the opportunity/possibility to serve in the body and that those things that hinder or impede the service of the believers are eliminated (Versteeg, 1988:49).

It must be pointed out that while some of the other services in a congregation could also function as a group for the good of the whole congregation, their service competence remains limited to the service they render. In contrast, one of the characteristic features of the official ministry is that its service competence affects all the other services in the congregation. 


\subsection{Functionalization and horizontalization}

Functionalization and horizontalization form another area in which questions with regard to the offices are being asked in contemporary discussions.

When considering an office in a functionalistic sense, the question is not so much whether the office should be performing a definite service, but rather what the service to be rendered implies. In contrast, in a horizontalistic consideration, the service of the congregation is mainly directed at its fellowmen and thus it merely merges into a kind of fellowship (Trimp, 1982:116-117).

In the context of these two approaches the congregation is frequently known as the bearer of all God's intentions for the world. The peace (shalom is preferred) of the Kingdom of God must be demonstrated by the congregation in and to the world. This demonstration of peace is manifested when the diaconal service of the church makes itself effective by different forms of fellowship in society. This diaconate can extend from personal aid-rendering for common cares to socio-political involvement in the struggle against enslaving structures. Official ministries in the church, with their special commission, are not necessarily needed for this type of service-rendering. More suitable are innovative and creative leaders who can mobilize the "volunteer legion" (Trimp, 1988:238). As a result of this process the church merely becomes an institution for national spiritual health needing nothing more than a number of disconnected functionaries who can render aid to mankind by virtue of their expertise (Trimp, 1982:116-117). In this horizontal understanding of the task of the congregation /church the emphasis does not lie on Christ equipping His congregation through office bearers to establish faith and love, but the focus is on the congregation offering volunteers to the world for the liberation of mankind. This approach often results in the ministry of the Word ultimately fading into the background (Trimp, 1982:238-239).

Reformed theology must be certain of the function and purpose of offices in the church.

Versteeg believes that offices in the church are necessary because the charismatic structure of the congregation is not automatically present and 
does not function automatically (Versteeg, 1990:23; Ridderbos, 1966: 497). The indicative of the charismata does exist for the congregation: Christ has bestowed the gifts. The imperative attached to these gifts is, however, not always as evident in the life of the congregation as it should be. Ephesians 4:11, 12 states that Christ has equipped the believers for service and for building up His body, so that ultimately we will all come to unity in our faith and in our knowledge of God. Verse 15 urges us all to grow up into Christ. Believers, however, need support in this process because false teachers continually attempt to lead believers astray by their false doctrine. Through His gifts God has given aid specifically for this purpose.

According to Ephesians 4:12 it was the task of the apostles, prophets, evangelists and the pastors and teachers (the offices in the early church?) to equip the believers for their service and for building up the body of Christ. Different opinions exist whether this verse mentions three functions (equipment, service and building up), two functions (equipment and building up) or only one function of the offices. Nevertheless, it can be accepted that Ephesians 4:12 refers to only one function of the offices, namely the equipment of the believers. Only such an explanation is in accordance with verse 16 , where the building up of the body is seen as a function of the whole body (Versteeg, 1990: 26). The offices are given by Christ to equip the believers so that they can render their service with the gifts which they have received, in this way building up the body of Christ.

Ephesians 4:16 also offers a special perspective on the function of the office with regard to the church as the body of Jesus Christ, the Head.

Through a substantial etymological and semantic investigation, Versteeg arrives at the conclusion that the Dutch geledingen and voegselen should be translated justly and accurately as joints.

It is accepted that the haphe (joints), mentioned in Ephesian 4:16, denote the apostles, prophets, evangelists, pastors and teachers mentioned in verse 11 - the offices in the church. According to Ephesians 4:16, the service of the offices thus implies to be the joints of the body.

Haphè, a concept from the medical world of that time, not only denotes connecting links between the different parts of the body but also implies supply or channel routes for food to the different parts of the body. As a 
result of the service of the haphès, the whole body is knitted together into a unity. At the same time the haphès are also channels by means of which the body is provided with food (Versteeg, 1990:24; Roberts, 1963:158 f). Versteeg points out that reference to both these functions of haphe are present in Ephesians 4:16. On the one hand the unity of the body created by the service of the joints is referred to when the author of the letter to the Ephesians states that the different parts of the body fit together. On the other hand, it is stated that when every part of the body fulfils its function, the body builds up itself in love - the food is able to reach all the parts of the body by means of the supply channel. This dual function induces Versteeg to see the service of the offices in the church as co-ordinating (linking together) and stimulating (supplying food) (Versteeg, 1990:25). While it is possible for the different charismata in a congregation to surpass or even to counteract one another, the joints can prevent this: they join the parts of the body to form a unity. Van Ruler refers to the offices in the church as "ambtelijke gebinte" ('official ties') of the church (Van Ruler, 1952:55, Versteeg, 1990:24-25). At the same time, the different charismata in the congregation need to be be stimulated (nourished) continuously. The body does not grow on its own. The offices must provide the congregation with the necessary nourishment. When the members of the congregation are equipped, stimulated and nourished, all the members of the body can fulfil their functions; the body of Christ will build up itself in love; and it will grow towards Christ the Head (Versteeg, 1990:25). Versteeg believes that there is an order of precedence in the function of the offices. According to him, the co-ordinating function of the joints is to nourish the body and not the other way round. Ephesians 4 raises the need for the nourishment and the growth of the body, the growth towards Jesus Christ, and the growth to attain the measure of the fullness of Jesus Christ. This need thus actually becomes the focal point of the service work of the offices. In a certain sense one could speak of the 'curiological' service that the offices have in respect of the other members of the body of Jesus Christ.

Summing up, we can say that Ephesians 4:12 and 16 give us a general description of the purpose and function of all offices in the church. It is the task of every office in the church to equip the believers to render their service, to nurture themselves for it and to co-ordinate themselves into a 
unity as the body of the Lord Jesus. By means of this process, the deeply devoted behevers, both as individuals and as a body, become as perfect and as mature as Jesus Christ.

Ephesians 4:12, 16 indicates that the functions of offices in the church imply the equipment, nourishment and binding together of the congregation so that they can achieve the measure of the fullness of Christ. These Scripturally interpreted tasks of the offices in general, and of certain offices in particular in the course of the churchs' history, must find a form under definite circumstances (either social, political, geographical or otherwise). The tasks, as such, fundamentally belong to the existence of the church of Christ. The forms they assume vary from time to time and according to the exigencies of circumstances. A given church therefore should find the best form of expression to perform the functions that Christ has commanded the offices. There is always the danger that a church will put its own form on a par with Scripture. Church polity and church government therefore should always be theologically attuned to and critical of the functioning forms devised and implemented in a particular time.

In conclusion, Reformed theology is not concerned merely with whether certain functions are being performed in the church. Of equal importance is the question: by whom and for what purpose are those functions performed in the church? There is such a thing as a basic order for the church that must be kept in mind and which must be obeyed. Furthermore, these functions do not only entail aid to mankind by virtue of certain expertise. Offices in the church are primarily there to serve Jesus Christ and His rule in the life of His followers: this means equipping the members of His body so that they can render service and come to the fullness of Christ where He is everything in everybody.

\subsection{Charisma and office}

There are individuals who operate from a spiritualistic point of view in which they contrast charisma and institution when they reflect on the offices of the church. They cannot accept a theological justification for office in the church and regard an institution as inferior to the work of the Holy Spirit. According to these people the Holy Spirit turns man's face to God with the result that man's back is turned on the banalities of 
humanity. From this point of departure there can be no Biblicaltheological justification for an office in the church. As a human society, the church necessarily requires leaders and therefore one finds leaders in the church. This is not a Biblical necessity but because people spontaneously come to the fore by virtue of free charisma. According to Trimp, one finds these protests against offices as a Biblical imperative in certain utterances of the Methodism, in many forms of the so-called evangelical Christiandom, in Congregationalism, as well as in certain forms of Independentism (Trimp, 1982:116).

In the life of the believers, both in the church and in His Kingdom, the one grace (charis) of God, through the all-powerful working of the Holy Spirit leads to a variety of actions/functions and qualifications or charismata and services, as they are called inter alia by Paul (cf. Lombard, 1976:43, 46). All these actions, functions and qualifications are designed/given to equip and build up the congregation so that it can attain the full greatness of Christ. This building up is a continuous process and concerns the individual believer. It, however, also concerns the church. As a unity, the church must grow to perfection and must reveal in its existence the fullness of the grace it possesses in Christ.

Service is the typical way in which gifts function in the congregation. Charismata can hence also be seen as service in the church - in fact it is in its service character that the destination and criterion of charismata lie (cf. 1 Peter 4:10, 11). Thus the charismata/services should always focus on the glorification of God in Christ as its ultimate aim (cf. Ephesians 4:12; 1 Corinthians 14:26; Colossians 3:16, 17).

These charismata/services in the church are not in contrast to the so-called institutionality of the church. On the contrary, the charismata incline towards the institutional. Throughout the New Testament there is clear evidence of the stability, the orderliness and progress, i.e. the institutionality of certain services and charismata in the church. The concept of service already carries the meaning of a particular activity performed by particular persons. It is not strange that beside the charismata of management reference is also made to leaders in the church (cf. 1 Corinthians 12:28 and Romans 12:8). Similarly the charismata are not only spoken of as powers but also as definite persons (cf. I 
Corinthians 12:28 and Ephesians 4:11). All these references indicate that the charismata are not given to the church on a here-and-now basis only but that a certain stability in structure and a way of functioning form part of the charismata which the Holy Spirit bestows on the church (Ridderbos, 1966:492-499).

When considering the requirements for elders, it would seem that preference for this service should be given to those church members who are particularly gifted in the areas of management, leadership, teaching and the ability to preach the Word. This does not necessarily imply a tension/distinction between the official ministry and other services in the church. The nature of the official ministry can be as charismatic as these other offices/services in the church. When writing his Pastoral letters, the latest of his letters, Paul paid more attention to official ministries. This fact must be seen against the background of the recipients of these letters, who were attempting to consolidate themselves into congregations based on the teaching of the apostolic tradition and doctrine. To do this effectively, they needed those charismata which Paul had indicated were basic and indispensable to the office of the presbyter-episkopos, namely the gift of management, the ability to teach, the ability to discern false from true doctrine and to have a lifestyle that was acceptable to outsiders (cf. $1 \mathrm{Tm}$. 3) Paul thus entrusted to the office of elder the care and supervision of the congregations so that these aspects would continue to be well-managed and cared for even should the apostles and their assistants no longer be there (Ridderbos, 1966:513).

In Reformed theology we can indeed say that official ministry is founded in the gifts (the charismata) that Jesus Christ gave to His church. By implication not only must the offices in the church serve with the charismata that have been given to them, but the church must also constantly ensure that each and every office bearer in the church is indeed a man/woman of God (1 Tm. 6:11).

\subsection{Authority}

One of the biggest problems which the office of the church has to face in our day is the challenge to its authority posed by the process of secularization. The status and authority originally bestowed on the offices clash with the modern view on authority. Modern man has reached so- 
called maturity. He upholds a democratic concept of authority which, essentially conflicts with the Biblical concept of authority despite apparent resemblances. This difference has far-reaching consequences concerning both the foundations and the nature of ministerial authority in the church. Consequently, it leads to all sorts of problems and tensions regarding the offices (Jonker, 1970:16). In the past, the authority of the offices in the church was generally accepted, especially the authority of the pastor, but the process of democratization has changed this. The authority of religious leaders is being challenged and their authority is no longer accepted without question. The ordinary members of the congregation claim that they also have gifts and a ministry to perform: it is not only the offices in the church which have authority. It is also argued that the offices receive their authority in a democratic way from the members of the church: they are therefore responsible to the church community for the way in which they exercise their authority (L.M. Heyns, 1993:359).

There are also those who think that the way in which the authority of the offices is exercised, in reality contradicts the image of servant figure which the Bible ascribes to offices. They therefore argue that offices in the church should only serve and not be authoritative positions at all.

Quite apart from the above viewpoints on the authority of the offices is the position held by Rome, which asserts that the authority of the office clings to the person of the office bearer. The office bearer receives this authority through the sacrament of ordination (sacramentum ordinis); thus in person becoming a representative of Christ (Hendriks, 1990:88 f).

Then there is also the view of those like W. Zijlstra, for whom the authority of the office rests with the attitude and communicative ability of the office bearer. This viewpoint eventually leads to an experience of liberation and revelation for the counselee (A.N. Hendriks, 1990:103109).

These differing viewpoints all challenge Reformed theology to be very sure of what it believes regarding the authority of the offices in the church.

Reformed theology has always maintained that the authority of the offices in the church can only be exercised to the extent to which they are bound to the service of the Word of God. It is not an authority that is given to the office bearer as a person: authority accompanies the service of the In die Skriflig 29(3) 1995:371-393 
Word of God. For this reason the authority of the office bearers in the church always has a service character. The office bearer has authority, not because he is in a specific office, but because as an office bearer he brings the Word of God, and as such, is a instrument in the hand of the Holy Spirit (Hendriks, 1990:84 f).

This means that an office bearer has no authority if he does not minister the Word of God to His congregation. This unique authority of the office bearer in ministering the Word is manifested inter alia in the authority to give peace to or to take it from a house; to give guidance to a congregation from the Word; to preach the Word; to lead in the practice of church discipline; and to co-ordinate, nourish and thus build up the congregation (Van Bruggen, 1984:37 etc.). Thus the ministerial service is also a service over and against the other services in the church (Versteeg, 1988:49). In this respect mention should be made of what Brockhaus terms "das rechtliche Element" (the judicial element) as characteristic of the ministerial service (Brockhaus, 1987:25). It also means that this service always has to be coupled with an authoritative supervisory function. Responsibility has to be accepted for the growth of the congregation towards Christ while at the same time adhering to the truth in love.

While Reformed theology cannot accept that the offices in the church are responsible to the congregation for their actions, it has always accepted the right of the congregation to judge the actions of the office in the light of Scripture. The congregation's role is thus not one of unconditional obedience, but rather one which continually tests the actions of the offices against what A.N. Hendriks calls the Magna Carta of the offices: the Word of God. In this way both the offices and the congregation must serve the authority of Jesus Christ in His Church (A.N. Hendriks, 1990:85-86).

\section{Conclusion}

Perhaps there is validity in the questions raised during the last few decades about the vitality of Reformed theology and its practices regarding the offices in the church. This might be the reason why Reformed theology has been attacked from so many different angles. These questions must be 
taken seriously, and Reformed theology must face its responsibility to ensure that its answers are well-grounded and theologically legitimate.

Part of the problem might lie in the fact that some people who held certain views' regarding the offices and their functioning, have not allowed their opinion to be subjected to theological criticism. Thus a church's concept of its offices can become rigidly hierarchical, democratic, bureaucratic, sacramentalistic or spiritualistic. Entrapped by such rigidity, it is easy for a church to be robbed of its vitality as the church of Jesus Christ.

Similarly, other fixed views can have a negative influence on a particular office concept and office functioning. For instance, all sorts of claims made by modern secular, democratic and sociological views can challenge the church's position. Of course this does not mean that Reformed theology and church practice must not take note of what is going on in other sciences or that the results in these fields cannot be of use. Before these results, however, can be incorporated into the church, they must be carefully scrutinized, using theological methods.

Maintaining/ensuring the vitality of Reformed theology, and particularly its view of the offices, will require that both church and theology remain vigilant in their assessment of their own view of the offices and of the way in which these offices function in practice. It will also mean that they must be open/willing to continually assess the validity of those questions raised and the proposals made regarding the offices in the church.

In addition to all this, Reformed theology must meet the challenge both to practise a theology and to ensure its implementation in the offices of the church in such a way that it is consistent with the basic principles of Reformed theology.

\section{Works consulted}

ANON. 1982. Baptism, Eucharist and Ministry. Faith and Order Paper no. 111. Geneva : World Council of Churches.

BERKHOF, H. 1970. Wat is er aan de hand met het ambt? Studierapport over het ambt, aangeboden door de generale synode van de Nederlandse Hervormde Kerk, krachtens besluit van haar vergadering van 18 Februarie 1969. 's Gravenhage : Boekencentrum N.V. 
BERKOUWER, G.C. s.j. Op de tweesprong. Wageningen : Zomer \& Keuning Uitgevers.

BROCKHAUS, U. 1987. Charisma und Amt. Die Paulinische Charismenlehre auf dem Hintergrund der frühchristlichen Gemeindefunktionen. Wuppertal : Brockhaus Verlag.

DEDDENS, K. 1988. Dient Hem met vreugde. Deel 1. Opstellen over de dienst van de ambtsdragers. Goes : Oosterbaan \& Le Cointre BV.

DEIST, F. 1989. Fundamentalisme - 'n Gereformeerde beoordeling. Theologia Evangelica, 22 (2):2-8.

DEKKER, G. 1992. De stille revolutie. De ontwikkeling van de Gereformeerde Kerken in Nederland tussen 1950 en 1990. Kampen : Kok. DINGEMANS, G.D.J. 1987. Een huis om in te wonen. Schetsen en bouwstenen voor een kerk en een kerkorde van de toekomst. 's Gravenhage : Boekencentrum B.V.

GREY, J. 1990. Predikant-wees vandag. 'n Prakties-teologiese visie op spesialisering én privatisering deur predikante van die Nederduitse Gereformeerde Kerk. Stellenbosch : Elise Grey Boeke.

HENDRIKS, A.N. 1990. Die alles in allen volmaakt. Een bundel praktischtheologische opstellen. Haarlem : AcaMedia.

HENDRIKS, H.J. 1990. Bediening in en deur die gemeente. 'n Praktiesteologiese basisteorie. Praktiese Teologie in Suid-Afrika, 5 (1):19-42.

HEYNS, J.A. 1992. Inleiding tot die Dogmatiek aan die hand van die Nederlandse Geloofsbelydenis. Pretoria : N.G. Kerkboekhandel 1988.

HEYNS, L.M. 1992. Die besondere amp - essensieel of funksioneel? Theologia Evangelica, 25 (3): 52-58.

HEYNS, L.M. 1993. Die amp in 'n krisis: 'n terreinverkenning. Nederduitse Geref Teologiese Tydskrif, 34 (3): 354-362, September

HOEKENDIJK, J.C. 1965. De Kerk binneste buite. Utrecht : Bosch.

JONKER, W.D. 1970. Als een riet in de wind ... Gedachten naar aanleiding van de huidige discussie rondom het ambt. Kamper Cahiers no 12. Kampen : Kok.

JONKER, W.D. 1994. Reformed Theology and the Identity of the Christian Congregation. Paper presented at the International congress on "The Vitality of Reformed Theology". Noordwijkerhout. The Netherlands, 20 24 June 1994.

LOMBARD, H.A. 1976. Charisma and Church Office. Neotestamentica, 10:13-52.

PELSER, G.M.M. 1990. Die bedieninge in die Nuwe Testament. 'n Ondersoek na historiese wording en prinsipiële regverdigbaarheid. Praktiese Teologie in Suid-Afrika, 5 (1):1-18. 
RICHARDS, L. \& MARTIN, G.A. 1981. A Theology of Personal Ministry. Spiritual Giftedness in the Local Church. Grand Rapids : Zondervan Publishing House.

RIDDERBOS, H. 1966. Paulus. Ontwerp van zijn theologie. Kampen : Kok.

ROBERTS, J.H. 1963. Die opbou van die kerk volgens die Efese-brief. Groningen : V.R.B. - Kleine der A 3-4.

STONEHOUSE, N.B. 1958. Fundamentalisme. In Christelijke Encyclopaedie deel III. Kampen : Kok. p. 93-94.

TRIMP, C. 1982. Ministerium. Een introductie in de reformatorische leer van het ambt. Groningen : Vuurbaak.

TRIMP, C. 1988. Ambt als dienst. (In Rossouw, P.J., red. Gereformeerde ampsbediening. Pretoria : NG Kerkboekhandel 1988.)

VAN BRUGGEN, J. 1984. Ambten in de Apostolische Kerk. Een exegetisch mozailk. Kampen : Kok.

VAN GENDEREN, J. \& VELEMA, W.H. 1992. Beknopte Gereformeerde Dogmatiek. Kampen : Kok.

VAN GINKEL, A. 1975. De ouderling. Oorsprong en ontwikkeling van het ambt van ouderling en de functie daarvan in de Gereformeerde Kerk der Nederland in de 16e en 17e eeuw. Amsterdam : Ton Bolland.

VAN RULER, A.A. 1952. Bijzonder en algemeen ambt. Nijkerk : Callenbach.

VAN RULER, A.A. 1965. Reformatorische opmerkingen in de ontmoeting met Rome. Antwerpen : Paul Brand.

VAN 'T SPIJKER, W. 1993a. Reformatie en Kerkorde. Theologia Reformata, 36 (3):178-201, September.

VAN 'T SPIJKER, W. 1993b. Tussenbalans. (In Van 't Spijker, W., red. Spiritualiteit. Kampen : de Groot Goudriaan, p. 307-329.)

VERSTEEG, J.P. 1988. Het karakter van het ambt volgens Efeziërs 4:7-16. (In Rossouw, P.J. red. Gereformeerde ampsbediening. Pretoria : N.G. Kerkboekhandel 1988. p. 49-74.)

VERSTEEG, J.P. 1990. Kijk op de kerk. De structuur van de gemeente volgens het Nieuwe Testament. Kampen : Kok.

VISCHER, L. 1990. Eldership in the Reformed Churches Today. Report of an International Consultation held at John Knox Centre in Geneva from August 26-31, 1990. 
